\title{
The Extent of Use of Analytical Procedures by External Auditors in Jordan in the Light of ISA 520
}

\author{
Hasan Flayyeh Al Qtaish ${ }^{1} \&$ Mohammed Hassan Makhlouf $^{1}$ \\ ${ }^{1}$ Faculty of Business, Isra University, Amman, Jordan \\ Correspondence: Hasan Flayyeh Al Qtaish, Faculty of Business, Isra University, Amman 11622, Jordan. E-mail: \\ hasan.alqtaish@iu.edu.jo
}

Received: January 10, 2019

Accepted: January 28, 2019

Online Published: February 18, 2019

doi:10.5539/ijef.v11n3p77

URL: https://doi.org/10.5539/ijef.v11n3p77

\begin{abstract}
The aim of this study was to identify the substance of the Audit Standard No. 520 concerning the analytical procedures, and evaluating the use of auditors in Jordan for the analytical procedures. Moreover, the study sought to make valuable recommendations to develop audit methods and address weaknesses to take advantage of financial analysis methods. To achieve the objectives of the study, questionnaire was developed included (38) questions distributed to a sample of auditors practitioners of the audit profession and numbered (46) auditors, have been recovered, (42) of them were collected, (41) Questionnaires were used in analysis; One sample t-test was used to test the hypotheses of the study. the researcher found: that the auditors are not using enough analytical procedures as the arithmetic average (3.49). Because they use financial ratios moderately where the arithmetic average (3.45), the arithmetic average of the comparable financial ratios and information extracted with pre-specified criteria (3.69). Finally, researchers suggested some of the recommendations of the most important need for the competent authorities to hold training courses, workshops and seminars related to the application of analytical procedures, and to verify the commitment and the work of audit firms auditors applying quality control standards, and be subject to peer review.
\end{abstract}

Keywords: ISA 520, analytical procedures, external auditor, Jordan

\section{Introduction}

International Standard on Auditing (ISA) 520 is pertinent to "Analytical Procedures". It includes analyzing ratios and significant trends of the financial statements, comparing the same with other information and the internal and external statements. It also includes verification of the existence of unforeseen relationships or pay attention to the existence of deviations or abnormal circumstances, to draw an opinion on the consistency of this information with what is known about the organization and its activities. This standard indicates that the use of analytical procedures is mandatory (Required) at the audit planning stage to enable the auditor to understand the client's activity and assess the risks of material distortions in the financial statements. It is also mandatory in the final phase of audit to enable the auditor to evaluate the different evidence and to conclude a final opinion on the integrity, fairness and reliability of the financial statements and to make judgment on the continuity of the business. The use of analytical procedures is optional in the substantive audit phase. Auditing is defined as a search for evidence. Analytical procedures are one of these audit evidence (Arens et al., 2012, p. 243) through which the auditor seeks to draw a proper opinion. This requires from the auditor to make a comparison between the financial statements and the ratios extracted with standards and information available with the company, industry and similar companies. To do that, the auditor must have sufficient competence, qualifications, and skills in both practical and scientific terms.

Based on the aforementioned discussions, this study seeks to draw the auditors' attention to the importance of analytical procedures as audit evidences. Thus, the study would give them an idea about the content and usefulness of conducting analytical procedures, in addition to the methods and mechanism of applying them. They could be applied by finding the ratios and indicators and compare them to the pre-set standards of horizontal analysis, vertical analysis and estimated budgets prepared by management and industry standards. Doing that would enable the auditor to understand the client's activity and determine the extent and scope of the detailed fundamental tests. It also enables the auditor to identify the ability of the organization to survive and continue its business, assess the risks of material distortions, evaluate different aspects of the organization's 
activity, and draw an impartial professional opinion on the fairness of the financial statements.

The present field study is intended to shed light on the content of Audit Standard No.520 by identifying the concept of analytical procedures and matters taken into account when conducting them, their objectives, the stages in which they pass and the use of these procedures. Furthermore, assessment the extent to which auditors are committed to using analytical procedures on auditing the industrial public shareholding companies in Jordan. Moreover, the study aims to identify weaknesses and provide proposals for the development of the audit process. Finally, this paper contributes to make some recommendations to enhance and develop of the method of the audit process and to develop solutions to avoid deficiencies by utilizing analytical procedures methods.

\subsection{Research Problem}

Analytical procedures are important audit evidence that directs the auditor to discover the relationships and expectations, as well as to determine the consistency of statements and any differences or unexpected relationships, and conclude the appropriate outcome on the fairness of such statement. The problem of this study lies in answering the following questions:

1) Are the auditors committed to the use of analytical procedures on their auditing of the industrial public shareholding companies?

2) To what extent do the auditors use the financial ratios on their auditing of the industrial public shareholding companies?

3) Does the auditor compare the financial ratios and the extracted information with the pre-determined standards (Financial analysis standards) on auditing the industrial public shareholding companies?

\subsection{Hypotheses}

Main Hypothesis: Auditors in Jordan use the analytical procedures on performing auditing of the Industrial Public Shareholding Companies.

This hypothesis is divided into two sub- hypotheses:

1) The auditors in Jordan use the financial ratios on performing auditing of the industrial public shareholding companies.

2) The auditors compare the financial ratios and resulting information to the pre-set standards (Financial Analytical Standards) on performing auditing of the industrial public shareholding companies.

\section{Theoretical Framework and Previous Studies}

\subsection{Previous Studies}

The study of (Kardudi, 2015) aimed to identify the role of using analytical audit in improving the performance of auditors in light of the need to use information technology in the Algerian economic institution. The study concluded that the analytical audit methods contribute to giving important warnings about the existence of manipulation in the financial statements and the discovery of core material errors. There is also statistical significance that the method of artificial networks is superior to the traditional statistical methods in their predictive ability and classification accuracy.

The study of (Saqqa et al., 2013) aimed to identify the extent to which the analytical procedures contribute to auditing the inventory by applying the analytical procedures on Acbetara Company, and enhance efficiency of auditors to understand how to use analytical audit. The study concluded several results; most important, the existence of materials are kept for periods exceeding the specific time limit, yet the company produces more of them. It was also found that there is a significant flaw in the internal control system.

The study of (Al-Abdali, 2011) aimed to identify the importance of using the analytical audit in the stages of auditing by the financial controllers. The study found out that among the factors that affecting the efficiency and effectiveness of auditing and control in the Ministry of Finance in the State of Kuwait is that the financial controllers are constrained by the timing analytical procedures performance; i.e. before, after or during the auditing period. In addition to deficiencies in the use of analytical procedures and the difficulty of obtaining the data necessary for conducting the analytical procedures.

The study of (Qrait, 2009) aimed to identify the extent to which analytical procedures were used by Syrian auditors in the different stages of auditing and to identify the importance of analytical procedures for the auditors. It was found that the use of analytical procedures was at low level by the Syrian auditors, and that there is a disparity in using those procedures despite they are used in all stages. 
The study of (al-Kubaisi, 2008) aimed to assess the effectiveness of analytical procedures in auditing the financial statements of public companies in point of view of auditors in Jordan. The results of the study were that the average effectiveness of the analytical procedures in auditing the financial statements of public companies ranges from average to good in all aspects, in terms of planning, auditing scope, discovering high risks affecting the organization, demonstration of appropriate disclosure, and low auditing cost.

\subsection{The Concept of Analytical Procedures}

Several studies discussed analytical procedures. The International Standard on Auditing (ISA) No 520 defines analytical auditing as the process of examining the information contained in the accounts and records of the organization, and comparing it with other information, besides internal and external statement, in order to conclude an opinion on the consistency of these information with what is known about the organization and its activities.

It is also defined as analyzing the relationships between the financial and non-financial statements items for the same period and compare it with the financial and non-financial information for other periods (Messier et al., 2006, p. 145), in order to identify the consistency of information and any differences, fluctuations or unexpected relationships. Thus, conclusion of the results of such tests (al-Dhneibat, 2015, p. 211; Wittington \& Pany, 2004, p. 141).

(Dahdouh et al., 2012, p. 331) pointed out that the analytical procedures cover important ratios and indicators, including examining the fluctuations and conflicting relationships with other related information that deviate from the planned amounts.

(Juma', 2012, p. 325) considers that the analytical procedures consist of an assessment of financial information by examining the fluctuations identified and the relationships inconsistent with other appropriate information or deviate greatly from the predicted amounts. It is also based on using of comparisons and relationships to determine whether certain account or statement seems logical (Arens \& Lubic, 2005, p. 217).

(Boynton \& Johnson, 2006, p. 246) considers that the analytical procedures include an assessment of financial information by calculating and comparing financial indicators using horizontal analysis and comparing actual statement with historical statements, budgets and the use of statistical methods.

Comparisons, according to (Fadhl \& al-Khateeb, 2008, p. 170), are deemed evidence in auditing. Comparisons are made between the financial statements items during the same period or several previous fiscal periods to detect any substantial changes or deviations to judge validity, honest, and fairness of the financial statements.

The researcher considers that auditing requires an assessment of the financial information using the analytical comparison by the auditor through comparing the financial statements and ratios with the information available, whether for the company itself (its past and its future) or with the industry in the application of Standard (520).

\subsection{The Importance and Purpose of Analytical Procedures}

Analytical procedures achieve several purposes, including:

1) Enabling the Auditor to understand the customer activity and risk assessment of the existence of material deviations concerning financial statements, to have an appropriate idea about the customer's activity by comparing the financial rations of the customer with other organizations in the same industry.

2) It may direct the auditor to some financial problems encountered by the customer (Al-Dhneibat, 2014, p. 215).

3) It may lead to reduction of volume of fundamental test (Abu Zaid et al., 2008, p. 243).

4) Identifying the scope and extent of compliance and fundamental test, as well as enhancing the results of auditing performed. (Audit Bureau, 1998, p. 26)

5) (Arens \& Lubic, 2005, p. 155) pointed out that the purpose of analytical procedure is to assess the ability of the organization to continue its business, in addition to indicate any possible deviation in the financial statements.

As made clear by the foregoing, the analytical procedures has a significant role as audit evidence in risk evaluation, the existence of material misstatement in the financial statements, identification of the scope of fundamental tests and the assessment of the organization ability to continue its business.

\subsection{Timing and Stages of Analytical Auditing}

The analytical procedures are performed through three stages; planning, substantial (detailed) tests and final 
stage (Kardoudi 2015, p. 18). The use of analytical procedures in both planning and final stages is compulsory (required) and optional in the substantial tests stage (Gliem, 2007, p. 60; Suza, 2004, p. 244).

\subsection{The Reliance on Analytical Comparison}

The implementation of analytical comparison relies on several factors, including:

1) The relative importance of the item under examination (Abu Zaid et al., 2008, p. 243), if the relative importance of the item is high, it is necessary to rely on other things to get out of the item under auditing.

2) Taking into account the results of other procedures applied on the same item or activity, identifying its consistency with the results of analytical procedures (al-Dneibat, 2015, p. 216; Audit Bureau, p. 27)

3) Forecasting the results of analytical procedures. This means the extent of compatibility between the analytical procedures and the expected results of these procedures (al-Dhneibat, 2010, p. 216).

4) Strength and solidity of internal control.

5) The reliability of the financial statements to be relied on, so that the procedures give correct significant indicators (Qreit, 2013, p. 443).

\subsection{Means and Methods of Performing Analytical Comparison}

1) The auditor shall carry out a comparison of the balances and financial ratios of the customer with the ratios and balances using one or more of the following analytical procedures (Arens et al., 2006, pp. 209-210; Arens \& Loebbecke, 2005, p. 190):

2) Compares the data and financial ratios of the customer with the industrial data of similar companies.

3) Comparing the current financial statements and financial ratios of the customer with similar ratios and statement of previous years.

4) Comparing the financial statements of the customer with the customer's expectations (pre-set estimate budgets).

5) Comparing the data of the customer with the auditor's expectations.

6) Performing comparisons between the financial data with the expectations using non-financial data; such as wage costs analysis with the number of employees.

(Mohammad et al., 2008, pp. 84-85) considers the study of the ratios in their absolute numerical form may not provide sufficient implications, and therefore assessing the importance of ratio reached requires comparing it with certain standard to be assessed substantively. There are four types of standards; industry standards/sectoral standards, historical standards, administrative/planning standards, and ideal standards.

(Mohammad et al., 2008, pp. 39-41; Gibson, 2001, pp. 162-163) pointed out that one of the most important analytical procedures; a) Vertical analysis, b) horizontal analysis, c) analyzing by using the ratios.

Ratios are one of the most important financial analysis tools and the most prevalent among financial analysts. We can put many ratios, but it is important to put the ratios that are important in assessing the different aspects of the organization.

The researcher considers that the methods of analytical procedures often concentrate on deriving ratios and indicators, and comparing them with predetermined standards, such as, the performance of previous years, estimated budgets, performance of similar companies, industry and sectorial standards and with non-financial related data.

The most common classification is classifying the financial ratios into five divisions: liquidity ratios, profitability ratios, capital structure ratios, activity ratios and market ratios (Khanfar et al., 2009, p. 129).

A) Profitability Ratios: these ratios measure the earning power(capacity) of the organization, management efficiency in using assets to generate sales and hence profit. Profitability analysis focuses on the following ratios:

1) Gross profit margin: this ratio measures the capacity per JD sales to generate total profit.

2) Operating profits margin: this ratio measures the ability per JD sales to generate operational profit (before interest and tax).

3) Net profit margin: this reflects the ability per JD sales to generate net profit after tax.

4) Return on Assets (ROA): This ratio measures the ability of each JD assets to generate net profit after tax.

5) Earning Power: This ratio provides an indication of the capacity of the organization management to use its 
assets to generate sales, thus generate profits. Turnover of assets rate is one side of earning power equation of the organization.

6) Operational cash ratio: This indicator measures the capacity of net profit to generate operational cash flow (Mohammad et al., 2008, p. 164).

B) Liquidity Ratios: Liquidity ratios are used as tools to assess the ability of an organization to pay its short-term liabilities. The ratios used to assess liquidity are: (Arens et al., 2003, p. 216):

1) Current Ratio: This ratio reflects the amount of coverage provided by current assets for current liabilities.

2) Quick-Acid Ratio: This ratio indicates the organization's ability to pay its short-term liabilities from its quick convertible assets to cash, thus excluding inventory and Expenses paid in advance.

3) Cash Ratio: This ratio indicates the capacity of the organization to pay its short-term liabilities from its cash and quasi-cash assets.

4) Cash Coverage Ratio: This ration indicates the adequacy of net cash flow from operational activities to cover investment and financing commitments (Mohammad et al., 2008, p. 165).

C) Turnover or Activity Ratios: These ratios are interested in the adequacy of operational assets (Mohammad et al., 2008, p. 76). They include:

1) Accounts Receivable Turnover: This measure expresses the ease and speed of converting receivables to cash during the financial period. It indicates the efficiency of managing funds invested in receivables.

2) Average Collection Period: This indicator measures the period by the average between the point of sale and the date of collection.

3) Inventory Turnover: The measure reflects the number of times that stores are emptied through sales during the financial period.

4) Average Storage Period (Leopold et al., 1998, p. 423): This indicator measures the average period at which inventory is kept in storage before sale.

5) Accounts Payable Turnover: This indicator measures the relation between Net forward purchases and Accounts Payable

6) Average Credit Period $=(365 /$ Payables Turnover $)$. This indicator measures the average time limit that creditors give to the organization.

7) Net Working Capital Turnover: This indicator measures the ability of working capital to generate sales.

8) Total Assets Turnover: This indicator reflects the capacity each JD invested in assets to generate sales and the efficiency of management in the use of assets.

D) Structure Ratios: These ratios, called Solvency Ratios, serve as tools to assess the ability of the organization to meet its long-term liabilities. The most important ratios used in this area are:

1) Foreign Financing to Assets ratio: This indicator indicates the extent to which the organization relies on debts to finance its assets.

2) Internal Financing to Assets ratio: This indicator indicates the extent to which the organization relies on its internal sources to finance its assets.

3) Long-term debts coverage ratio: This ratio reflects the extent to which fixed assets provide long-term debts coverage.

4) Debts to Equity ratio: this measure shows the components of capital structure from debts and equity.

5) Fixed assets financing ratio: this ratio reflects the extent of coverage provided by the permanent funds to long-term debt and property rights to fixed assets.

6) Current Assets financing ratio: this ratio reflects the coverage provided by the current assets to the current liabilities.

E) Market Ratios: These ratios serve the dealers in the capital market (Matar, 2006, p. 67). This set of ratios include:

1) Earnings per share (EPS): this ratio measures the share of normal share of profits.

2) Dividends pershare (DPS): this ratio measures the cash amount each shareholder will be receive for each share he owns. 
3) Book Value per share: this ratio measures the increase achieved in equity of the company. The higher its value, it is evidence of company's performance (Matar, 2006, p. 73).

4) Market value per share to book value ratio: this ratio shows the relationship between the market value and book value of the share.

\section{Methodology}

\subsection{Study Community and Sample}

Study community consists of Auditors in Jordan. Some were selected upon their specialization in this area. The sample members were (46) auditors. Questionnaires have been distributed to all of them; 42 were collected and 41 only were valid and subject to analysis, i.e. (97.62\%) of the collected questionnaires, which is the sample of this study.

\subsection{Study Tool}

An instrument was developed to achieve the purposes of this study through reviewing the theoretical literature of Audit Standard 520 pertinent to analytical procedures, in addition to the relevant previous studies. In order to develop this tool, it has been relied on five point Likert Scale. The degree weights used were as follows: (very large) represents 5 degrees, (large) represents 4 degrees, (average) represent 3 degrees and (weak) represents 2 degrees, (not used) represents 1 degree. The questionnaire paragraphs were distributed into (38) paragraphs to cover all the study variables as follows:

1) Paragraphs from (1-31) measure the extent to which auditors use financial ratios on auditing the industrial public shareholding companies. The ratios were divided into five groups, namely:

2) Paragraphs (1-4) measure the degree of use of liquidity ratios, paragraphs (5-11) measure the degree of use of profitability ratios, paragraphs (12-17) measure the degree of use of structure ratios, paragraphs (18-27) measure the degree of use activity ratios or turnover rates, and paragraphs (28-31) measure the degree of use of market ratios.

3) Paragraphs (32-38) measure the extent to which auditors compare financial ratios and information extracted by pre-determined standards (financial analysis standards) on auditing the industrial public shareholding companies.

\subsection{Reliability and Stability of Study Tool}

The study tool was presented to a number of colleagues from university professors in accounting departments and specialists in the field of auditing and financial analysis, for the purpose to examine it and give their points of view on the proper formulation, correlation of its paragraphs and relevance to the subject matter developed for.

In addition, Kronbach's Alpha coefficients of internal consistency were extractedto measure the internal consistency of questionnaire paragraphs. Cronbach's alpha coefficient was (0.8544) among all the (38) questionnaire paragraphs. Cronbach's alpha coefficient among the paragraphs intended for the measurement of auditors use of the financial ratios on auditing the industrial public shareholding companies was (0.8720). It was (0.8584) among the paragraphs that measure the comparison of financial ratios and extracted information in the pre-set standards. These values indicate that the scale is high stability coefficient.

\subsection{Statistical Methods Used}

In order to answer the study questions, SPSS was used in the analysis, through using the following statistical methods:

1) Descriptive Statistic Measures, represented in the arithmetic means, standard deviation, frequencies and percentages.

2) One Sample T-test

3) Cronbach's alpha for internal consistency.

To determine the degree of use, the following weights have been used:

Table 1. Answers weights

\begin{tabular}{cc}
\hline Average answers & Degree of use \\
\hline $1-2.33$ & Weak \\
$2.34-3.66$ & Average \\
$3.67-5.00$ & High \\
\hline
\end{tabular}




\subsection{Characteristics of the Study Sample}

Table 2. Characteristics of the sample members by: sex, age, academic qualification, specialization, length of service, and position $(\mathrm{N}=41)$

\begin{tabular}{llll}
\hline Variable & & No & $\%$ \\
\hline Sex & Male & 30 & 73.2 \\
Age & Female & 11 & 26.8 \\
& Less than 30 & 32 & 78.0 \\
& $30-35$ & 8 & 19.5 \\
Academic Qualification & $40-35$ & 1 & 2.4 \\
& Bachelor & 35 & 85.4 \\
Specialty & Higher education & 6 & 14.6 \\
& Accounting & 39 & 95.1 \\
Length of service & Other & 2 & 4.9 \\
& Less than 5 years & 26 & 63.4 \\
Position & 5-10 & 12 & 29.3 \\
& $10-15$ & 3 & 7.3 \\
& Auditor & 19 & 46.3 \\
& Key Auditor & 7 & 17.1 \\
& Assistant auditor & 13 & 31.7 \\
\hline
\end{tabular}

The data of Table 1 shows that the high representation percent of male $(73.2 \%)$, while the representation of female was $(26.8 \%)$. In terms of age, the highest percent of respondents is age group of less than 30 years old (78.0\%), followed by the group 30-53 years old (19.5\%). The highest percent of academic qualification variable is $(85.4 \%)$ of Bachelor Degree, and the rest $(14.6 \%)$ for higher education. In terms of specialization, we note the high percentage of accounting specialization by $(95.1 \%)$, while the other specialties is $(4.9 \%)$.

The data of the table also shows the distribution of study members according to length of service. We notice that the highest percent is for those who are less than 5 years of service $(63.4 \%)$, while the lowest percent represents those who are (10-15) experience (7.3\%). In terms of positions; we note that (46.3\%) of the sample members are Auditors, followed by (31.7\%) assistant auditor, then Assistant key auditor position (17.1\%), Assistant manager and advisor (2.4\%) for each.

The researcher finds out from the foregoing that the vast majority of the members of the study sample are those who have disciplines relevant to the subject matter of this study (accounting). The majority of them are practitioners of audit work. All the members of the study sample have the appropriate academic qualifications, bachelor and higher education, which will have a positive impact on the results of the study.

\subsection{Statistical Processing}

\subsubsection{Arithmetic Means and Standard Deviations}

- The use of financial ration on auditing the industrial public shareholding companies:

1) Liquidity Ratio

Table 3. Arithmetic means, standard deviations and the degree of using the liquidity ratio $(\mathrm{N}=41)$

\begin{tabular}{|c|c|c|c|c|c|}
\hline Ser. & Paragraph & mean & $\begin{array}{c}\text { Standard } \\
\text { deviation }\end{array}$ & Rank & $\begin{array}{c}\text { Degree of } \\
\text { Use }\end{array}$ \\
\hline 1 & Current Ratio $=$ current assets/ Current liabilities & 3.83 & 0.77 & 1 & High \\
\hline 2 & Quick-Acid Ratio $=($ current assets - inventory - prepaid expenses $) /$ current liabilities & 3.34 & 0.66 & 2 & Average \\
\hline 3 & Cash flow ratio $=($ cash assets + equivalent cash $) /$ current liabilities & 3.29 & 0.78 & 3 & Average \\
\hline \multirow[t]{2}{*}{4} & $\begin{array}{l}\text { Cash coverage ratio = net cash flow from operational activities/ total external cash flow } \\
\text { for investment and financing activities }\end{array}$ & 3.15 & 0.85 & 4 & Average \\
\hline & Overall & 3.40 & 0.61 & --- & Average \\
\hline
\end{tabular}


Table 3 shows that the degree of the use of liquidity ratio is average. The overall average responses of the scale is (3.40) with standard deviation (0.61). It also shows that the degree of use of three paragraphs is average, and high degree of use of one paragraph that is paragraph (1). Average of responses is (3.83) with standard deviation (0.77).

\section{2) Profitability Ratio}

Table 4. Arithmetic means, standard deviations and degree of use the profitability ratio $(\mathrm{N}=41)$

\begin{tabular}{clcccc}
\hline Ser. & \multicolumn{1}{c}{ Paragraph } & mean & $\begin{array}{c}\text { Standard } \\
\text { deviation }\end{array}$ & Rank & Degree of Use \\
\hline 5 & Gross profit margin = total profits/ net sales & 4.10 & 0.74 & 1 & High \\
6 & Operating profits margin = net operational profit/ net sales & 3.88 & 0.90 & 3 & High \\
7 & Net profit margin = net profit after tax/ net sales & 3.90 & 0.94 & 2 & High \\
8 & Return on Assets (ROA) = net profit after tax/ average of total assets & 3.46 & 0.78 & 4 & Average \\
9 & Earning power = operational profit margin/ working assets turnover rate & 3.15 & 0.76 & 6 & Average \\
10 & Operational cash ratio = net operational cash flow/net profit & 3.05 & 0.95 & 7 & Average \\
11 & Cash flow Ratio = total cash flow gained from operational activities/ net & 3.27 & 1.00 & 5 & Average \\
& sales & & & & Average \\
& Overall & 3.54 & 0.62 & ---- & Aver
\end{tabular}

Table 4 shows that the degree of profitability use is average. To overall average of responses of the scale is (3.54), with standard deviation (0.62). It is noted that the degree of use of four paragraphs is average and three paragraphs is high (paras 5, 6, and 7).

\section{3) Capital Structure Ratios}

Table 5. Arithmetic means, standard deviations and degree of use of capital structure ratios $(\mathrm{N}=41)$

\begin{tabular}{clcccc}
\hline Ser. & \multicolumn{1}{c}{ Paragraph } & mean & Standard deviation & Rank & Degree of Use \\
\hline 12 & Long term debts coverage ratios = net fixed assets/long term debts & 3.54 & 0.98 & 3 & Average \\
13 & Liabilities ratio = total liabilities/ equity & 3.78 & 0.88 & 1 & High \\
14 & Ratio of financing current assets = current liabilities/ current assets & 3.66 & 0.99 & 2 & Average \\
15 & Internal financing to asset ratio = equity / total assets & 2.90 & 0.74 & 5 & Average \\
16 & Financing fixed assets ratio = (long term debts + equity)/ net fixed assets & 2.85 & 0.82 & 6 & Average \\
17 & External funding to assets ratio = total liabilities/ total assets & 3.15 & 0.76 & 4 & Average \\
& Overall & 3.31 & 0.58 & --- & Average \\
\hline
\end{tabular}

Table 5 shows the average degree of the use of capital structure ratio. The degree of use of four paragraphs is average and one degree of use one paragraph is high, which No. (13), with arithmetic mean of answers (3.78) and a standard deviation (0.88). The overall arithmetic mean is (3.31) and standard deviation (0.58).

\section{4) Activity Ratios}

Table 6. Arithmetic means, standard deviations and degree of use of activity ratios $(\mathrm{N}=41)$

\begin{tabular}{|c|c|c|c|c|c|}
\hline Ser. & Paragraph & mean & Standard deviation & Rank & Degree of Use \\
\hline 18 & Receivables Turnover Rate $=$ net forward sales/average receivables & 4.02 & 0.88 & 2 & High \\
\hline 19 & Average collection period $=360$ days $/$ receivables turnover rate & 4.05 & 0.86 & 1 & High \\
\hline 20 & Stock turnover rate $=$ cost of sold goods $/$ average inventory & 3.78 & 0.61 & 3 & High \\
\hline 21 & Average of storage period $=360$ days/inventory turnover rate & 3.54 & 0.71 & 4 & Average \\
\hline 22 & Payables turnover rate $=$ net forward purchases $/$ average payables & 3.17 & 0.63 & 5.5 & Average \\
\hline 23 & Average Credit period $=360$ days $/$ payables turnover rate & 3.17 & 0.63 & 5.5 & Average \\
\hline 24 & Assets turnover rate $=$ net sales $/$ average assets & 2.95 & 0.67 & 9 & Average \\
\hline 25 & Fixed assets turnover rate $=$ net sales $/$ average Fixed assets & 2.93 & 0.72 & 10 & Average \\
\hline 26 & Current assets turnover rate $=$ net sales $/$ average current assets & 3.02 & 0.76 & 8 & Average \\
\hline \multirow[t]{2}{*}{27} & Net working capital turnover rate $=$ net sales/ average net working capital & 3.15 & 0.79 & 7 & Average \\
\hline & Overall & 3.38 & 0.54 & --- & Average \\
\hline
\end{tabular}


Table 6 shows that degree of use the activity ratio is average. We notice that degree of use seven paragraphs is average while the degree of use of three paragraphs is high (which are No 18, 19, 20) with arithmetic mean of answers $(4.02,4.05,3.78)$ respectively. The overall average of answers (3.38) with standard deviation $(0.54)$.

\section{5) Market Ratios}

Table 7. Arithmetic means, standard deviations and degree of use of market ratios $(\mathrm{N}=41)$

\begin{tabular}{|c|c|c|c|c|c|}
\hline Ser. & Paragraph & mean & Standard deviation & Rank & Degree of Use \\
\hline 28 & $\begin{array}{l}\text { Earnings per Share }(E P S)=\text { (net profit after tax }- \text { preference shares } \\
\text { distribution)/ average of number of existing regular shares }\end{array}$ & 4.10 & 0.89 & 2 & High \\
\hline 29 & Dividend per share $(\mathrm{DPS})=\mathrm{DPS} /$ average of the number of regular shares & 3.63 & 1.13 & 1 & Average \\
\hline 30 & $\begin{array}{l}\text { The ratio of the market value per share to book value }=\text { market value per } \\
\text { share/ book value per share }\end{array}$ & 3.34 & 1.20 & 3 & Average \\
\hline \multirow[t]{2}{*}{31} & Book value of equity per share (BVPS) $=$ equity/ number of shares & 3.68 & 0.91 & 4 & High \\
\hline & Overall & 3.69 & 0.89 & --- & High \\
\hline
\end{tabular}

We note from the data of Table 7 that the degree of use market ratios is high. The average overall of answers in the scale is (3.69) with standard deviation (0.89). We also not the degree of use two paragraphs is average and two paragraphs is high, which are No. 28 and 31 with arithmetic mean 4.10 and 3.68 respectively.

From the foregoing, the researcher found out that the application of the financial ratios of the five groups is average, except the market ratios, which high. The above result can be explained by the fact that the study sample members of auditors may not have sufficient knowledge of standards on audit, in particular, the international Standard on auditing 520 related to the analytical procedures, in terms of its importance, stages of use, methods, financial analysis instruments, and its role in drawing auditor's professional opinion.

- Comparing the financial ratios and extracted information with predetermined standards (financial analysis standards) on auditing the industrial public shareholding companies

Table 8. Arithmetic means, standard deviations, degree of use of comparison of financial ratios and extracted information with the predetermine standards

\begin{tabular}{|c|c|c|c|c|c|}
\hline Ser. & Paragraph & mean & $\begin{array}{l}\text { Standard } \\
\text { deviation }\end{array}$ & Rank & $\begin{array}{l}\text { Degree } \\
\text { of Use }\end{array}$ \\
\hline 32 & $\begin{array}{l}\text { The auditor compares the extracted ratios and the financial statements with historical } \\
\text { criteria (previous years), i.e. horizontal analysis. }\end{array}$ & 4.02 & 1.11 & 1 & High \\
\hline 33 & $\begin{array}{l}\text { The auditor performs the vertical analysis of the budget (item value/total budget) and the } \\
\text { income statement (item value/Net sales) and compares it with previous years. }\end{array}$ & 3.93 & 1.13 & 2 & High \\
\hline 34 & $\begin{array}{l}\text { The auditor compares the financial ratios with the administrative standards (estimated } \\
\text { budgets). }\end{array}$ & 3.44 & 1.12 & 7 & Average \\
\hline 35 & The auditor compares the financial ratios with industry standards or similar companies. & 3.63 & 1.11 & 5 & Average \\
\hline 36 & The auditor compares the financial ratios with local or external standards. & 3.46 & 1.10 & 6 & Average \\
\hline 37 & $\begin{array}{l}\text { The auditor compares the extracted ratios and the financial statements with the auditor's } \\
\text { expectations of the results. }\end{array}$ & 3.71 & 0.75 & 3 & Average \\
\hline \multirow[t]{2}{*}{38} & $\begin{array}{l}\text { The auditor compares the financial information of the current year with relevant } \\
\text { non-financial information. }\end{array}$ & 3.66 & 0.82 & 4 & Average \\
\hline & Overall & 3.69 & 0.76 & --- & High \\
\hline
\end{tabular}

Table 8 shows that there is a high degree of use of the financial ratios and information extracted with the pre-determined standards. The overall average of answers in the scale is (3.69) and the standard deviation (0.76). For the paragraphs, most of the paragraphs are average degree. The degree of comparison of four paragraphs is average and three paragraphs degree is high, which are No. $(32,33,37)$. The arithmetic means of the answers are (3.93 and 3.71) respectively.

The result can be explained by the fact that the auditor may be not sufficiently aware of the importance of audit standard related to the analytical procedures. The auditor may face some difficulties in conducting analytical procedures; for example, the lack of sufficient knowledge in comparison procedures, and the lack of standards on which the measurement and comparison are made, such as estimated budgets, industry standards and similar 
companies.

\subsubsection{Hypotheses Testing}

Main Hypothesis: The auditors in Jordan use the analytical procedures on auditing the industrial public shareholding companies.

Table 9. The results of one sample t-test

\begin{tabular}{cccccc}
\hline mean & Standard deviation & $\mathrm{t}$ - value calculated & Degree of freedom & Statistical significance & The result of hypothesis \\
\hline 3.49 & 0.35 & 9.058 & 40 & $* 0.000$ & Accepted \\
\hline *differences of statistical significance at significant level $(\alpha \leq 05)$.
\end{tabular}

The results of the one-sample t-test show that there are statistically significant differences at level $(\alpha \leq 05)$ between the average answers on the overall degree of the scale (3.49) and average of default scale (3). Calculated (T value) is (9.058), which higher than critical ( $\mathrm{t}$ value) at the significance level (0.05)and degree of freedom (40) which is (1.684). Therefore, the hypothesis is accepted.

First Sub-Hypothesis: The auditors in Jordan use the financial ratios on auditing the industrial public shareholding companies.

Table 10. The results of one sample t-test

\begin{tabular}{cccccc}
\hline mean & Standard deviation & $\mathrm{t}$ - value calculated & Degree of freedom & Statistical significance & The result of hypothesis \\
\hline 3.45 & 0.38 & 7.479 & 40 & $* 0.000$ & Accepted \\
\hline
\end{tabular}

*differences of statistical significance at significant level $(\alpha \leq 05)$.

The results of the one-sample t-test show that there are statistically significant differences at level $(\alpha \leq 05)$ between the average answers on the overall degree of the scale of the auditors in Jordan use the financial ratios on auditing the industrial public shareholding companies (3.45) and average of default scale (3). Calculated (T value) is (7.479), which is higher than the critical ( $t$ value) at the significance level (0.05) and degree of freedom (40) which is (1.684). Therefore, the sub-hypothesis is accepted.

Second Sub-Hypothesis: The auditors in Jordan compare the financial ratios and extracted information with the pre-determined standards (financial analysis standards) on auditing the industrial public shareholding companies.

Table 11. The results of one sample t-test

\begin{tabular}{cccccc}
\hline mean & Standard deviation & $\mathrm{t}$ - value calculated & Degree of freedom & Statistical significance & The result of hypothesis \\
\hline 3.69 & 0.76 & 5.860 & 40 & $* 0.000$ & Accepted \\
\hline
\end{tabular}

*differences of statistical significance at significant level $(\alpha \leq 05)$.

The results of the one-sample t-test show that there are statistically significant differences at level $(\alpha \leq 05)$ between the average answers on the overall degree of the scale of the comparison of the financial ratios and extracted information with the pre-determined standards (financial analysis standards) on auditing the industrial public shareholding companies (3.69) and average of default scale (3). Calculated (T value) is (5.860), which is higher than the critical ( $\mathrm{t}$ value) at the significance level (0.05) and degree of freedom (40) which is (1.684). Therefore, the second sub-hypothesis is accepted.

\section{Conclusion and Recommendations of the Study}

\subsection{Results of the Study}

By analyzing the results and testing the hypotheses, the study reached the following conclusions:

1) The auditors in Jordan do not use the analytical procedures sufficiently and there is a disparity in the use of these analytical procedures when they audit the industrial public shareholding companies.

2) The use of the financial ratios by the auditors was not sufficient, as the overall arithmetic mean was (3.39) at average degree of use. The use of both liquidity ratios, profitability ratios, capital structure ratios and turnover rate ratios were as follows: (3.40), (3.54), (3.31), (3.38) respectively, and the degree of use is average each. The use of market ratios was high, as its average degree of use was (3.40). 
3) The application of analytical procedures by comparing the financial ratios and the information extracted with the predetermined standards (financial analysis standards) was at average degree for most of the paragraphs. The overall arithmetic mean is (3.69) with high degree.

\subsection{Recommendations}

Based on the results obtained, the researcher recommends the following:

1) The supervising authorities are required to follow up and supervise the work of auditors and to conduct specialized training courses on analytical procedures based on the international standard on audit No (520).

2) The Jordanian Association of Certified Public Accountants have to conduct training courses, workshops, seminars on the application of the analytical procedures.

3) The supervising authorities have to ensure that audit offices and auditors works must comply with application of the quality control and must be subject to peer review.

4) The supervising authorities on audit profession, in cooperation with competent bodies, should develop standards adopted by different sectors to be used by the auditors for the purpose of auditing, conducting comparisons and evaluating the performance.

5) The Jordanian universities and institutions must teach the international audit standards, in particular Standard (520) on analytical procedures, especially the practical aspect of the standard.

\section{References}

Abdullah, K. A. (2000). Auditing. Amman, Jordan: Dar Wael Printing \& Publishing.

Abu, Z., Kamal, K., Issa, S. K., \& Rashed, R. Al-Sayyed. (2008). Studies in External Audit of the Financial Statement. Alexandria, Egypt: The University Press House.

Al- Abdali, S. H. (2011). The Importance of Using Analytical Procedures in Auditing Stages by Financial Controllers. Unpublished Master Thesis, Middle East University, Amman, Jordan.

Al-Thuneibat, A. (2015). Auditing in the light of the International Accounting Standards. Amman, Jordan: Dar Wael printing and publishing.

Arens, A. A., Elder, R. J., \& Beasely, M. S. (2003). Auditing and Assurance Services. Practice Hall, Nourth Carolina State University.

Arens, A. A., Elder, R. J., \& Beasely, M. S. (2012). Auditing and Assurance Services. Practice Hall, Nourth Carolina State University.

Arens, A., \& Lubeck, J. (2008). Review, Integrated Introduction. Translated by Mohammad Al-Desaitiand Ahmad Hamed Hajjaj, Dar Al-Mareikh for Publishing, Riyadh: Saudi Arabia.

Audit Bureau. (1998). Circular No 32 of 1998. Government Audit Standards. Amman, Jordan.

Boynton, W. C., \& Johnson, R. N. (2006). Modern Audit. John Wiley \& Sons, Inc.

Dahdouh, H. A., \& al-Qadi, H. Y. (2012). Advanced Auditing. Amman, Jordan: Dar Al Thaqafa for Publishing and Distribution.

Dhneibat, A. A. Q. (2010). Audit in the light of International Accounting Standards. Amman, Jordan: Dar Wael printing and publishing.

Gibson, C. H. (2001). Financial Reporting Analysis. South -Western Collage Publishing.

Gliem, I. N., \& Hillison, W. A. (2007). CPA Review Auditing and Attestation. INC, first Printing.

Juma', A. H. (2012). Introduction to Auditing and Assurance in accordance with International Standard on Audit. Amman, Jordan: Safa Publishing House.

Kardoudi, S. (2015). The Role of Analytical Review in Improving the Performance of the Auditor in light of the need for the use of information technology in the Algerian economic institution. Unpublished doctoral thesis, Mohammed Khaydar University, Biskra, Algeria.

Khanfar, M. R., \& al-Matarneh, G. F. (2009). The financial statements. Dar al Maseerah, Amman, Jordan.

Kubaisi, A. S. A. J. (2008). Evaluation of the Effectiveness of Analytical Procedures for Auditing the Financial Statements of Public Shareholding Companies. Anbar University Journal of Economic and Administrative Sciences, (2), 1-29.

Leopold, A. B., \& John, J. W. (1998). Financial Statement Analysis (6th ed.). MCGraw- Hill Book C-Singapore. 
Matar, M. (2006). Recent Trends in Financial and Credit Analysis. Amman, Jordan: Dar Wael Publishing.

Messier, W., Glover, S. M., \& Prawitt, D. (2006). Auditing and Assurance Services. Mc Graw- Hill, Irwin. United State.

Mis'ad, M. F., \& al-Khateeb, K. R. (2008). In-depth Study of Auditing. Amman, Jordan: Dar Al-Ma'rifahal-Ilmiyyah for Publishing and Distribution.

Muhammad, M. S., Ismail, I., \& Noor, A. N. (2008). Financial Analysis, Introduction to Decision Making. Amman, Jordan: Dar Wael Publishing.

Qreit, I.(2009). The Use of Analytical Procedures in Syrian Arab Republic. Journal of Damascus University for Economic and Legal Sciences, 25(1), 431-454.

Saqqa, A., \& al-Qadi, H. (2013). The Contribution of Analytical Procedures in Stock Review. Damascus University Journal of Economic and Legal Sciences, 29(2), 433-461.

Suza, D. D. (2004). Advanced Auditing. Taxman Allied Services(p.) Ltd, Dilhi, India.

Tamimi, H. (2006). Introduction to Auditing. Amman, Jordan: Dar Wael Printing \& Publishing.

Whttington, O., \& Pany, K. (2004). Priciples of Auditing and Other Services. Mc Graw- Hill, Irwin. Singapore.

\section{Copyrights}

Copyright for this article is retained by the author(s), with first publication rights granted to the journal.

This is an open-access article distributed under the terms and conditions of the Creative Commons Attribution license (http://creativecommons.org/licenses/by/4.0/). 